\title{
The Effect of the Post-Socialist Transition on Inequality of Educational Opportunity: Evidence from German Unification
}

\author{
Bastian Betthäuser* \\ University of $\mathrm{Oxford}$
}

ABSTRACT: In 1990, German unification led to an abrupt and extensive restructuring of the educational system and economy of the German Democratic Republic (GDR) as the latter was reintegrated into the Federal Republic of Germany (FRG). However, the consequences of this largescale institutional change for the educational inequality between children from different social class backgrounds in East Germany continue to be poorly understood. This article seeks to shed new light on this question by using a quasi-experimental approach to examine the difference in educational inequality between East and West Germany before and after German unification. We compare changes in the class gradient in educational attainment in East and West Germany across six birth cohorts, including three cohorts of individuals who completed their schooling after unification. Contrasting with past findings, our results show that before unification, educational inequality at the mid-secondary, upper-secondary and tertiary level was substantially lower in East Germany than in West Germany and that unification led to a substantial and sustained convergence of the level of educational inequality in East Germany towards that of West Germany.

Published version: Betthäuser, B. A. (2019). The Effect of the Post-Socialist Transition on Inequality of Educational Opportunity: Evidence from German Unification. European Sociological Review 35(4): 461473, doi: $10.1093 /$ esr/jcz012

* Nuffield College, University of Oxford, 1 New Road, Oxford OX1 1NF, UK bastian.betthaeuser@nuffield.ox.ac.uk 


\section{Introduction}

The ideological basis of the German Democratic Republic (GDR) as a 'worker and peasant state' mandated a strong commitment to educational equality and the promotion of educational opportunities for working-class youth (Fischer, 1992; Below, 1997). The ruling Socialist Unity Party of Germany (SED) sought to achieve this goal by fundamentally restructuring the GDR's educational system and economy during the post-war transition to communism (Geißler, 1983; Connelly, 2014). Accordingly, the Law for the Democratisation of the German School that was passed in 1946 stated that "[...] the new school system must be structured in a way that guarantees to all youth, girls and boys, children from urban and rural areas, independent of the economic resources of their parents, an equal right to education and its realisation according to their ability and predisposition" (as cited in Fischer, 1992, p. 34, author translation).

The substantial restructuring of the educational system and economy that occurred in the GDR and other state-socialist regimes of Central and Eastern Europe renders them a large-scale historical experiment in increasing equality of opportunity by way of institutional reform (Szelényi, 1998). Amongst all state-socialist countries, the reform trajectory of GDR is particularly well suited for empirical analysis. Not only were the educational system and the economy of the GDR fundamentally restructured under state socialism, but this restructuring was then abruptly reversed with German unification in 1990, when the GDR was reintegrated into the Federal Republic of Germany (FRG). Moreover, the strong institutional continuity of the FRG's education system and economy throughout the second half of the twentieth century makes the FRG a robust control case, demonstrating the development of educational inequalities in the absence of state-socialist reforms and their reversal with unification.

Despite the unique reform trajectory of East Germany, there continues to be little evidence on the extent to which the GDR succeeded in reducing educational inequality between children from different social class backgrounds, and on whether these achievements were subsequently reversed after unification. Some studies found a decline in inequality of educational opportunity (IEO) in the early years of the GDR (see e.g., Below, 1997; Geißler, 1983). Yet, these studies tend to draw on official statistics from the GDR that are of questionable reliability and do not allow for a precise measurement of individuals' parental class background. ${ }^{1}$ Moreover, there is some evidence of an increase in IEO in the GDR starting in the mid-1970s (Solga, 1997; Geißler, 1983). This finding is consistent with the 'socialist transformation hypothesis', which expects an initial decline in IEO as socialist reforms are implemented, but suggests that these early gains are lost as parents in advantaged positions adapt to the changed institutional context and find new ways to advantage their children (see Blossfeld and Shavit, 1993; Szelényi, 1998). However, it is not clear whether in the late phase of the GDR, the level of IEO in the GDR had reverted fully towards that of the FRG, or whether working class children in the GDR still had better educational prospects than their peers in the FRG. 
Evidence on changes in IEO in other state-socialist countries is mixed. With regards to Hungary, Bukodi and Goldthorpe (2010) find a decline in IEO in the early period of state socialism and a subsequent increase in later years as the country transitioned to a market-based economy (also see Szelényi and Aschaffenburg, 1993, and Szelényi, 1998). A similar pattern is found in Russia by Gerber and Hout (1995). However, with regards to Czechoslovakia and Poland, Mateju (1993) and Heyns and Bialecki (1993) find that educational inequality between individuals from different social backgrounds did not decline or may even have increased compared to the presocialist period.

Aside from the lack of comparable evidence on the level of IEO in the GDR and the FDR before unification, few studies have systematically examined whether and to what extent the level of IEO in the GDR changed with the fundamental restructuring of the GDR's educational system and economy in the wake of German unification. A notable exception is the study by Kesler (2003), which seeks to examine the level of IEO in East and West Germany before and after unification. However, Kesler acknowledges several serious limitations of her study. First and most importantly, the small sample used in in Kesler's study puts it at risk of making a type II error (false negative), i.e. concluding that there are no differences between her comparison groups, when in fact such differences exist. This casts doubt on the robustness of Kesler's findings that there was little difference in IEO between East and West Germany before unification, and that IEO did not increase after unification in East Germany.

A second limitation of the study by Kesler - in part due to the study having been conducted only about a decade after German unification - is that it compares only one pre-unification cohort and one post-unification cohort, as opposed to examining over-time change across multiple cohorts in East and West Germany. This prevents her study from identifying whether a potential change in IEO after unification reflects only a short-lived effect that may be due to the economic crisis triggered by unification, or whether unification had a sustained effect on IEO which may be attributed to the institutional restructuring of the East German educational system and economy.

Third, Kesler's study is limited in that it only considers IEO in terms of individuals' completion of upper-secondary education. Therefore, it remains unclear whether potential differences in IEO between East and West Germany pre- and postunification apply to the upper-secondary level only, or whether they are already visible at the mid-secondary level and carry through to the tertiary level.

Kesler's finding that IEO did not increase with German unification contrasts with studies of other post-socialist countries, which generally find an increase in the intergenerational transmission of inequality after the post-socialist transition (see Gerber and Hout, 2004, on Russia, Lippényi and Gerber, 2016, and Bukodi and Goldthorpe, 2010, on Hungary; and the cross-national study by Jackson and Evans, 2017). However, as discussed in further detail below, these studies are themselves limited in that they tend to only focus on one or more (post-)socialist countries, and 
thus lack a control case that would permit them to identify the observed over-time changes in inequality as resulting from the post-socialist transition per se, as opposed to other over-time trends at the time that are not primarily related to the post-socialist transition.

The main aim of this article is to overcome the abovementioned limitations of the existing literature in order to address the following two research questions: First, was IEO lower in East Germany than in West Germany before unification? Second, if such east-west difference in IEO existed before unification, did the level of IEO in East Germany increase and converge towards the level of IEO in West Germany after unification? In order to address these two questions, we compare the level of IEO between individuals from different social class backgrounds in East and West Germany across six five-year birth cohorts: 1960-64, 1965-69, 1970-74, 1975-79, 198084, 1985-89. This multiple cohort design and the use of West Germany as a comparison case allows us to distinguish the unification effect from potentially confounding over-time trends in IEO. Furthermore, it enables us to examine both the short and long-term consequences of German unification. Rather than relying on official statistics from the GDR, we work with data from two German survey programmes which provide comparable information on the social class backgrounds and educational careers of a large sample of East and West German individuals. As discussed in further detail below, we focus our analysis on school and university qualifications that are substantively comparable across the GDR and the FRG.

\section{Why expect IEO to be lower in the GDR than in the FRG?}

With the goal of breaking the 'educational privilege' of the middle and upper classes and to advance the educational and labour market chances of individuals from working-class backgrounds the Socialist Unity Party of Germany (SED) radically restructured the educational system and economy of East Germany after the Second World War (Geißler, 1983; Below, 1997). This interventionist approach by the GDR leadership stands in sharp contrast to the liberal educational and economic policies of the FRG, which largely upheld the institutional structure of the pre-war period.

One key reform implemented by the GDR leadership was the universalisation of education up until the mid-secondary level and the abolishment of the traditional tripartite structure that allocated students into a lower-secondary, mid-secondary and upper-secondary school track after primary school (Below, 1997). This tripartite system had been in place before the war and prevailed in the FDR thereafter (Cortina et al., 2008). In the GDR, it was replaced by a comprehensive school, the Polytechnische Oberscbule (POS), which jointly schooled all children until grade ten (Below, 1997). Contrasting with the universalisation of mid-secondary education, upper-secondary education in the GDR continued to be highly selective. Importantly however, the GDR administration implemented a series of 'counter-privileging' measures that were designed to facilitate the access of children from working-class backgrounds to the upper-secondary school, the Erweiterte Oberschule (EOS). Accordingly, the selection of 
pupils into upper-secondary school was not only based on their performance, but also depended on their social background - by way of a quota system that positively discriminated in favour of children from working-class backgrounds - and on the 'political attitude and societal engagement' of children and their parents (Marggraf, 1993). Moreover, the GDR provided several alternative avenues for obtaining the Abitur, including via advanced dual vocational training (the Berufsausbildung mit Abitur) and via so-called Worker and Farmer Colleges (Arbeiter-und-Bauern-Fakultäten) (Geißler, 1983). By contrast, in the FRG alternative routes to the Abitur were relatively scarce and admission to the upper-secondary school track was primarily based on teacher recommendations as well as parents' preferences (Cortina et al., 2008).

Both the universalisation of mid-secondary education and the 'counterprivileging' measures at the upper-secondary level can be expected to have decreased cross-class inequalities in educational attainment at the mid- and upper-secondary level in the GDR. This may be expected to further have translated into increased educational equality at the tertiary level, which is likely to have been reinforced by the provision of stipends for children from working-class backgrounds and targeted publicity campaigns (Bildungswerbung) that informed members of the working class and the rural population of the benefits of pursuing higher education (Geißler, 1983).

Aside from the educational reforms discussed above, the flattening of the income distribution in the planned economy of the GDR (Speder and Habich, 1999) may also have had a bearing on the educational inequality between children from different parental class backgrounds. More specifically, the reduced level of inequality in the economic resources that parents in different social class positions could devote to the development and education of their children - e.g., via providing additional tutoring and learning materials - can be expected to have further decreased IEO in the GDR, relative to the FRG. ${ }^{2}$

It is also conceivable that the motive of status maintenance in educational decision making - which has been central to sociological explanations of the intergenerational transmission of inequality (see Breen and Goldthorpe, 1997) - was less prominent amongst parents and children in East Germany prior to unification, given the ideological commitment of the GDR to equalising individuals' socioeconomic position. Moreover, in as far as the motive of status maintenance was still a concern amongst individuals, it may be the case that employment guarantees and the importance of political capital for individuals' labour market position in the GDR made individuals from advantaged backgrounds less dependent on and therefore less invested in maximizing their educational attainment in order to maintain their parents' social status.

While the educational and economic characteristics of the GDR reviewed above would lead one to expect a lower level of IEO in the GDR, as compared to the FRG, it is important to note potentially countervailing forces that may have moderated or offset potential advances in equalising educational opportunity in the GDR. As suggested by the abovementioned socialist transformation hypothesis (Blossfeld and Shavit, 1993), parents from higher social class positions may have adapted to the 
counter-privileging reforms in the GDR by finding new ways of leveraging their economic, political and cultural resources to advantage their children. This expectation has received some support by research suggesting that that the political elite in the GDR used their political clout to advance their children's educational and labour market careers (see Solga, 1994). Such dynamic may have been reinforced by the substantial in-kind privileges - such as luxury homes and goods - that accompanied high political office in the GDR (see Lenski, 1994) and by the founding of 'special schools' (Spezialschulen) that predominantly admitted students from privileged social backgrounds (see Opitz, 1979; Meier and Reimann, 1977). ${ }^{3}$ It thus remains an empirical question to what extent the GDR succeeded in realising its ideological commitment to reducing the level of IEO.

\section{Why expect a unification effect on IEO in East Germany?}

German unification in 1990 led to an abrupt reintegration of the educational system of the GDR into that of the FRG. Starting in 1991 pupils in East Germany found themselves attending the same type of schools as their West German peers. Similarly, the East German economy was remoulded along the lines of West Germany's social market economy in a rapid process of economic liberalisation. The radical institutional reconfiguration of the East German educational system and economy contrasts with what can be described as a frozen landscape of institutional stasis in West Germany at the time of unification (see, e.g., Cortina et al., 2008).

The assimilation of the East German educational system into the West German model meant that universal schooling until the mid-secondary level was abolished and ability tracking into different school types after fourth grade was reintroduced. ${ }^{4}$ At the same time, the abovementioned measures of positive discrimination in favour or working class youth at the secondary and tertiary level were abandoned (Mintrop and Weiler, 1994). Considering the likely equalising effects of the reforms of the educational system in the GDR discussed in the previous section, the reversal of these reforms with German unification can be expected to have led to an increase in IEO in East Germany (i.e. the former GDR) after unification. Given the known class-gradient in lower-secondary attainment in West Germany (Blossfeld, 1993; Betthäuser, 2017), the re-introduction of the lower-secondary school track and the lower-secondary qualification (Hauptschulabschluss) is likely to have increased the proportion of children from working-class backgrounds who leave school before obtaining a mid-secondary qualification, thus increasing IEO at the mid-secondary level. Similarly, the abolition of positive discrimination in favour of working-class youth and the removal of the vocational route to obtaining the Abitur can be expected to have led to an increase in IEO at the upper-secondary and tertiary level.

Key reforms of the East German economy included the liberalisation of prices and trade and the privatisation of previously state-run businesses in the span of four years (Mayer 2006; Gebel, 2011; Windorf, 1996). These reforms stood in sharp contrast to the planned economy of the GDR. As was the case for most other former 
member states of the soviet bloc, the East German 'shock therapy' was more shock than therapy and led to a deep economic recession that was accompanied by a vast increase in unemployment, economic insecurity and income inequality (Hunt, 2008; Hauser and Becker, 2000; Gebel, 2011). Given the likely rigidifying consequences of economic recessions for IEO (see Jackson and Evans, 2017), the crisis may have reinforced the effects of the educational restructuring on IEO in East Germany after unification. In our analysis, we therefore examine both the short-run effect of German unification on IEO, which may be magnified by the effects of the economic recession, and the long-run effect, which can be taken to reflect the institutional changes that occurred with German unification.

\section{Method, data and variables}

The abrupt assimilation of the institutional structure of the East German educational system and economy into that of West Germany with unification constitutes a unique quasi-experimental setting for studying the effects of large-scale institutional change on IEO. We examine the effects of this institutional restructuring by way of a differencein-difference design, comparing the difference in IEO in East and West Germany before and after unification (Angrist and Pischke, 2009; Gangl, 2010). ${ }^{5}$ Using West Germany as a control unit allows us to examine whether any over-time change in IEO in East Germany is due to the institutional restructuring in the wake of unification, as opposed to other potentially confounding over-time changes. For this reason, using a differencein-difference design constitutes an advantage over existing studies of the post-socialist transition which lack a comparison unit (cf. Jackson and Evans, 2017; Gerber and Hout, 2004, Lippényi and Gerber, 2016, Bukodi and Goldthorpe, 2010).

We examine the level of educational inequality between individuals from different social class backgrounds in East and West Germany across six five-year birth cohorts: $1960-64,1965-69,1970-74,1975-79,1980-84,1985-89 .{ }^{6}$ The $1970-74$ cohort is the last cohort of individuals who received their full schooling before unification. We therefore use this cohort as the reference category in all our analyses. All members of the 1975-79 cohort made the transition to upper-secondary education after unification and the younger members of this cohort received their full secondary education in unified Germany. Similarly, all members of the 1980-84 and 1985-89 cohorts received their full secondary education after unification. Accordingly, if the institutional changes in East Germany in the wake of unification had an effect on IEO, we would expect to see a convergence in the level of IEO between East and West Germany in the younger three cohorts.

We use the German Socio-Economic Panel (SOEP) as the primary dataset for our analyses (see Wagner et al., 2007). In order to avoid any potential bias due to survey specificities, we replicate our results by running all our models on a secondary dataset. For this purpose, we use the German General Social Survey (ALLBUS/GGSS) (see Wasmer et al., 2014). All results from our replication analyses are reported in the Appendix. While most previous studies on educational and labour market inequalities 
in Germany use the 'complete case analysis' approach and thus rely on the assumption that missingness in the data is completely at random (White et al., 2010), we impute missing data points using multiple imputation by chained equations and thereby limit the risk of potential bias related to systematic item missingness in our data. ${ }^{7}$

The dependent variables of our analyses are three binary educational threshold variables, measuring first, whether individuals have attained a school qualification at the mid-secondary level or above, second, whether they have attained a school qualification at the upper-secondary level, and third, whether they obtained a university qualification. ${ }^{8}$ When comparing the level of educational inequality between individuals from different social backgrounds in the GDR and the FRG it is essential to work with measures of educational attainment that are comparable across the two countries. Attaining the mid-secondary school-leaving qualification was an important educational threshold in both the GDR and the FRG that is comparable across the two countries, since pupils in both countries had to complete ten years of general schooling to obtain this qualification. Likewise, the upper-secondary school qualification can be taken to indicate a similar level of schooling in the GDR and the FRG, since pupils had to complete a further two to three years of schooling after completing their midsecondary education. The upper-secondary school-leaving qualification constituted the precondition for enrolling in university in both the GDR and the FRG and was nominally identical in both countries (known as the Abitur). By contrast, vocational qualifications are not comparable across the two countries, since in the GDR vocational training certificates were at times awarded based on working experience alone and without further formal training, while in the FRG these qualifications necessitated further schooling in the Berufsschule, generally alongside completing an apprenticeship. We therefore focus our main analysis of educational attainment at the secondary-level on comparing school-leaving qualifications, rather than vocational qualifications. In order to remain consistent with our focus on general/academic education at the secondary level, we also focus our analysis of tertiary level attainment on academic tertiary education only, i.e. attainment of a university qualification. Similar to our measures of educational attainment at the secondary-level, obtaining a university qualification is comparable across the GDR and the FRG, while the system of vocational and more applied tertiary education differed substantially across in the two countries.

Our focal independent variable, parental class, is operationalised using the European Socio-Economic Classification (ESeC). The ESeC schema allocates individuals to different social class positions based on their occupation and employment status (see Wirth et al., 2010; Rose and Harrison 2010). This clear and transparent allocation principle allows for a consistent classification of parents in East and West Germany and permits us to avoid issues of comparability due to different interpretations of the meaning and scope of social class categories, which constitutes a serious limitation of previous studies of social inequality in the GDR (see, e.g., Below, 1997, and Geißler, 1983). 
We measure parents' social class position using a four-category version of the ESeC schema, differentiating between (1) the unskilled working class, (2) the skilled working class, (3) the intermediate class and (4) the salariat. We differentiate between individuals from unskilled and skilled working-class backgrounds, as it has been shown that there is a substantial difference in the mean educational attainment between these two groups in Germany (Betthäuser, 2017). However, given the ideological agenda of the GDR, we expect its reforms to have affected the educational attainment of individuals from working-class backgrounds at large. We derive the parental class position from fathers' and mothers' class positions using the dominance approach (Erikson, 1984). This approach allocates parents to a social class position according to the higher social class position of the two spouses. Parents' social class position is measured at age fifteen of the cohort members. We control for individuals' gender and age in all our models. ${ }^{9}$ The distributions of our focal variables are shown in Table A13 in the Appendix.

\section{Results}

As noted above, the first aim of this paper is to assess whether and to what extent IEO was lower in the GDR than in the FRG before unification. Second, we seek to examine whether, if such east-west difference in IEO existed before unification, the level of IEO in the East Germany increased and converged towards the level of IEO in West Germany after unification. To address these questions, we run a series of binary logit models for East and West Germany respectively with the three binary educational thresholds as the outcome variables. ${ }^{10}$ Our focal explanatory variables are individuals' parental class background and birth cohort. We present our results in the form of a series of figures showing the predicted probabilities of crossing the three educational thresholds for different social origin groups in East and West Germany. Tables reporting average marginal effects and their statistical significance are given in the Appendix (Tables A1-A6). We replicated all our results using the ALLBUS data (see Tables A7-A12 in the Appendix) and found the results to be highly consistent between the SOEP and the ALLBUS data.

Figure 1 shows the predicted probability of children from different social class backgrounds to obtain a qualification at the mid-secondary level or above, for each birth cohort in East and West Germany respectively. For the three birth cohorts of children who completed their schooling before unification, we observe, first, that the total share of pupils attaining an educational qualification at the mid-secondary level or above was higher in the GDR than was the case in the FRG. Second, we observe that IEO was substantially lower in the GDR than was the case in the FRG. ${ }^{11}$ Both the higher overall level of mid-secondary attainment and the lower level of educational inequality between individuals from working-class backgrounds and individuals from higher class backgrounds at the mid-secondary level may be a result of efforts in the GDR to universalise education up until tenth grade. However, Figure 1 also shows that even in the late phase of the GDR, there was still a substantial proportion of pupils 
who did not attain the mid-secondary qualification - thus leaving school without a qualification - and a considerable class gradient in mid-secondary attainment.

Figure 1. Predicted probabilities of obtaining a mid-secondary school-leaving qualification for different birth cohorts in West and East Germany

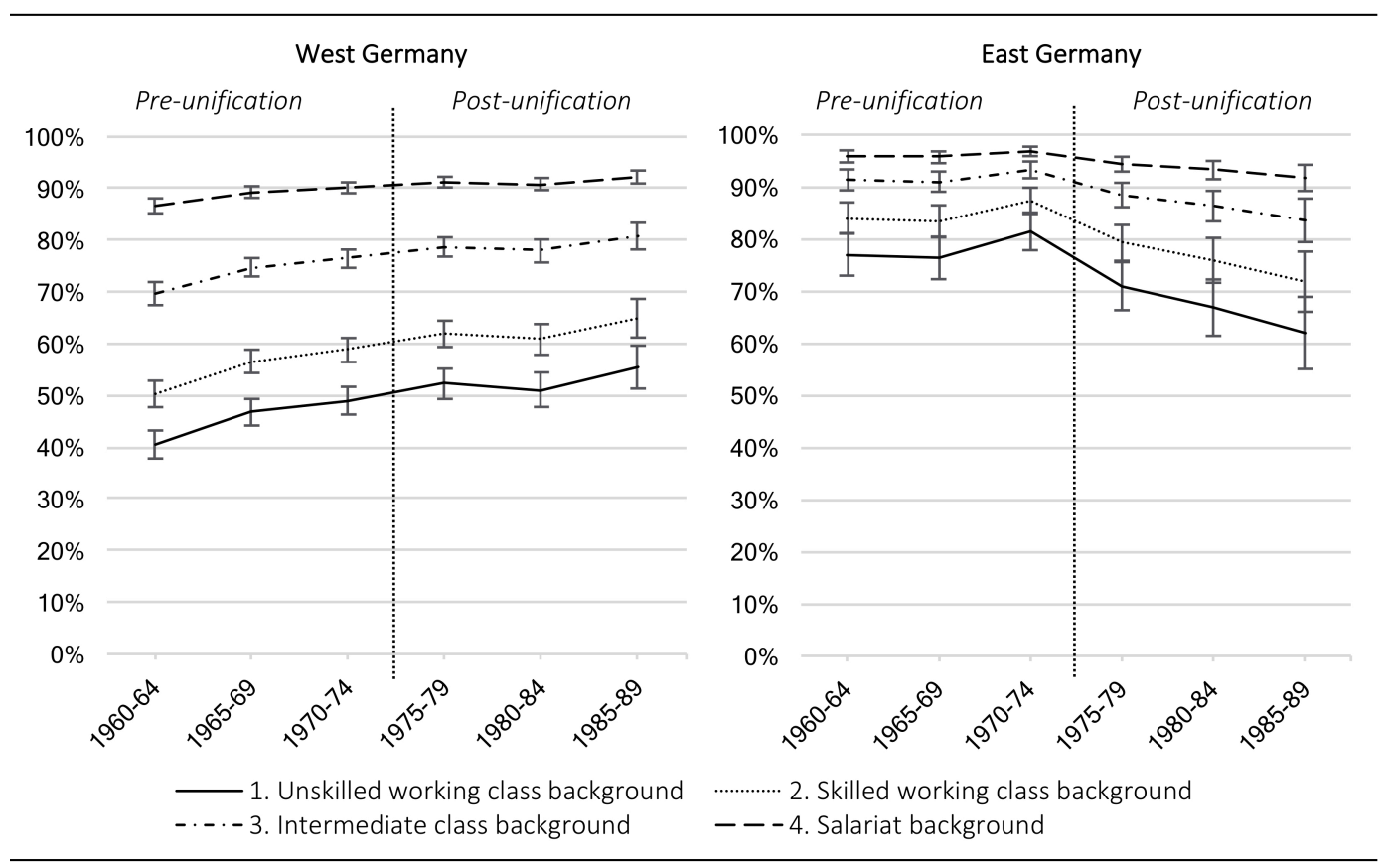

Notes: Predicted probabilities based on logistic regression models with the binary measure of obtaining a mid-secondary school-leaving qualification as the outcome variable (SOEP).

With regards to the effect of unification, we observe a notable drop in the overall proportion of pupils who obtain a qualification at the mid-secondary level or above between the third and fourth birth cohort in East Germany. This development likely reflects the reintroduction of the lower-secondary school track (Hauptschule) and the lower-secondary leaving qualification (Hauptschulabschluss) after unification. Importantly however, the drop in mid-secondary attainment appears to have been concentrated amongst children from working-class backgrounds, thus leading to an increase in the educational inequality between this group and individuals from intermediate class and salariat backgrounds. ${ }^{12}$ This increase in IEO appears to persist across the three birth cohorts who completed their schooling after unification, suggesting that it is not primarily a result of the post-unification economic crisis, but instead can be attributed to the institutional changes that occurred with unification. It is important to note, however, that despite a clear convergence in the level of inequality in mid-secondary attainment in East Germany towards that of West Germany, IEO at the mid-secondary level remained lower in East Germany compared to West Germany even after unification. ${ }^{13}$ 
Figure 2. Predicted probabilities of obtaining an upper-secondary school-leaving qualification for different birth cohorts in West and East Germany

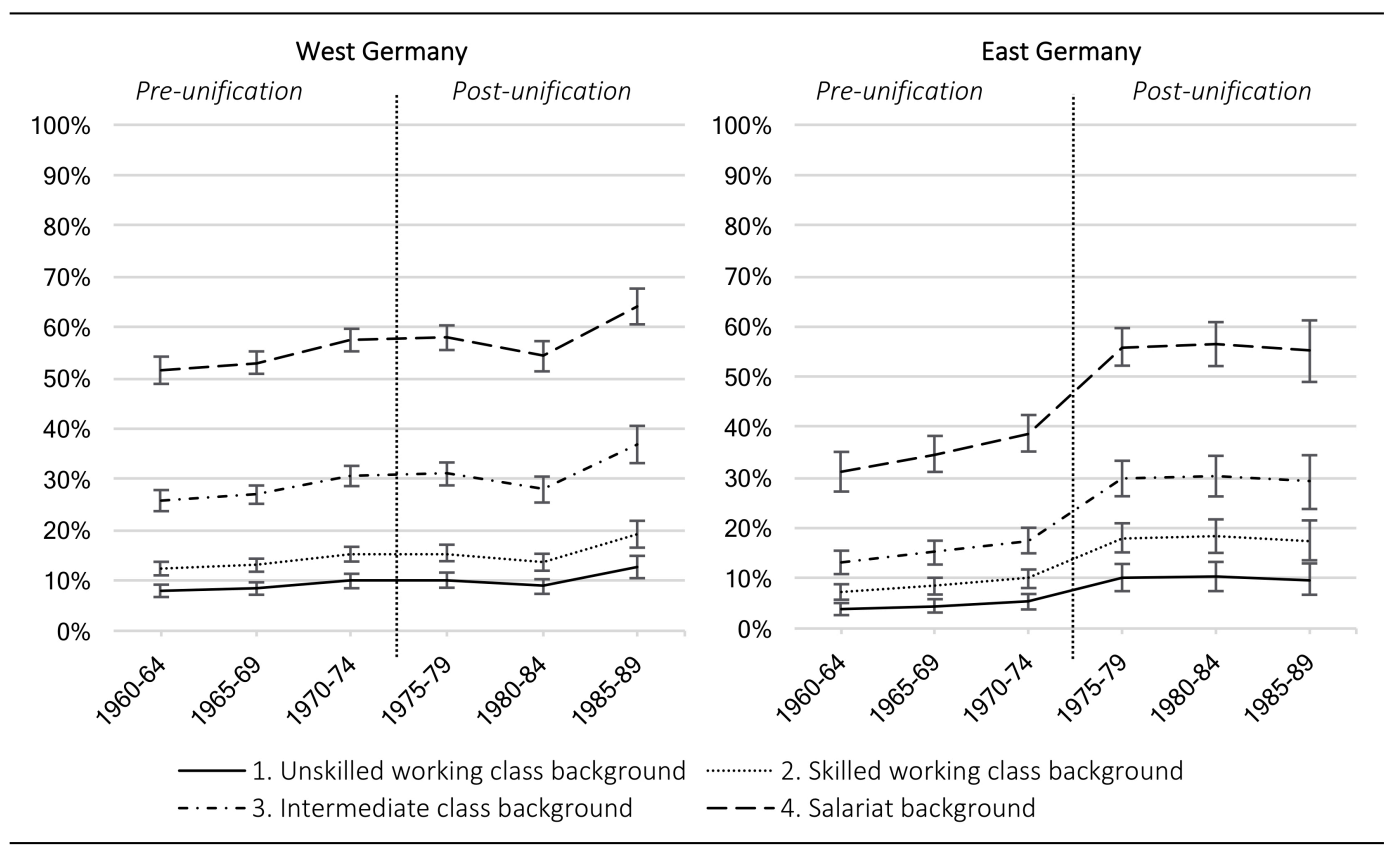

Notes: Predicted probabilities based on logistic regression models with the binary measure of obtaining an uppersecondary school-leaving qualification as the outcome variable (SOEP).

Figure 2 shows the predicted probabilities of attaining a qualification at the uppersecondary level for different social origin groups in East and West Germany respectively. In contrast to our findings for the mid-secondary level, for the three preunification cohorts we find that the overall share of pupils attaining an uppersecondary qualification was substantially lower in the GDR than in the FRG. This is likely to be a consequence of the restrictive admission requirements for uppersecondary enrolment in the GDR (Gebel, 2011). We also observe a considerable level of inequality in upper-secondary attainment in the GDR. Children from salariat backgrounds were about 25 percentage points more likely to obtain an uppersecondary qualification than was the case for children from working-class backgrounds. However, the left-hand panel of Figure 2 shows that in the FRG the level of inequality in upper-secondary attainment between children from salariat and working-class backgrounds was larger yet, at about 40 percentage points. ${ }^{14}$ Hence, while a considerable level of inequality in upper-secondary attainment remained in the GDR, the counter-privileging measures in the country appear to have succeeded in compressing cross-class inequality at this level, relative to the FRG.

Regarding the effect of unification, we observe a notable rise in the proportion of individuals who obtain the upper-secondary qualification between the third and fourth birth cohort in East Germany. This development is consistent with past findings and has been attributed to the relaxation of admission criteria and the founding of new upper-secondary schools (Gymnasien) in East Germany (Schreier, 1996; Below, 1997; Gebel, 2011). However, this rise in upper-secondary attainment appears to have mainly benefitted children from salariat and intermediate class 
backgrounds, while the probability of obtaining an upper-secondary qualification rose to a much lesser degree for children from unskilled and skilled working-class backgrounds. Consequently, IEO at the upper-secondary level in East Germany increased after unification and came to closely resemble the level of IEO in West Germany. ${ }^{15}$ Similar to the observed increase in inequality at the mid-secondary level, this rise in IEO at the upper-secondary level was sustained across all three postunification cohorts. It can thus not be attributed principally to the rigidifying effects of the economic post-unification crisis, but is likely to reflect the institutional changes that occurred with unification, particularly the re-introduction of early ability tracking and the abolishment of positive discrimination in favour of pupils from working-class backgrounds.

Figure 3. Predicted probabilities of obtaining a university qualification for different birth cohorts in West and East Germany

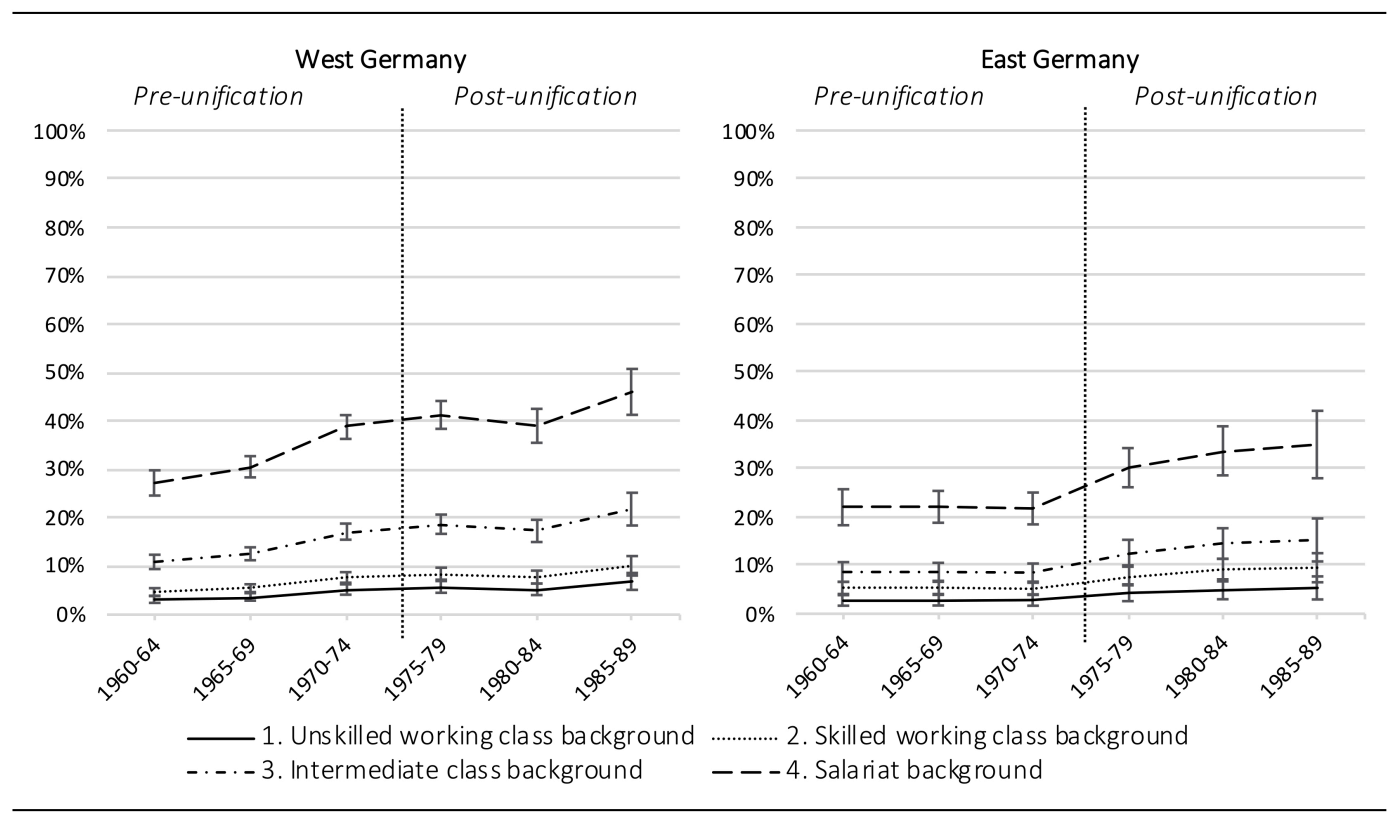

Notes: Predicted probabilities based on logistic regression models with the binary measure of obtaining a university qualification as the outcome variable (SOEP).

Figure 3 demonstrates that the east-west differences and over-time development in IEO at the upper-secondary level are mirrored at the tertiary level. For the three preunification cohorts, we find that the overall share of individuals attaining a tertiary qualification appears to have been notably lower in the GDR than in the FRG. Again, this is consistent with previous findings and has been attributed to the lower share of individuals who obtained an upper-secondary qualification in the GDR (Gebel, 2011; Kehm, 2004). While we observe a considerable gap in tertiary-level attainment between different social origin groups in the GDR, this gap was substantially larger in the FRG. ${ }^{16}$ This East-West difference in the inequality in tertiary-level attainment is likely to be a consequence of the lower degree of inequality in upper-secondary attainment in the GDR, relative to that in the FRG, and may also reflect the abovementioned 
provision of stipends for working-class youth and the publicity campaigns targeted at this group to inform them about the benefits of higher education (Bildungswerbung).

With unification, we observe a notable rise in the level of educational inequality between different origin groups at the tertiary level in East Germany after unification. As shown in Figure 3, after unification the level of IEO in East Germany almost completely converged towards the level of IEO in West Germany. ${ }^{17}$ This rise in IEO at the tertiary level after unification is sustained across the three post-unification cohorts and as such appears not to result mainly from the post-unification economic crisis. Instead it may be attributed to the sustained increase in inequality at the uppersecondary level and the abolishment of stipends and information campaigns targeted at individuals from working-class backgrounds in East Germany.

\section{Conclusion}

Using the FRG as a comparison case, this article has sought, first, to examine the extent to which state socialism in the GDR succeeded in reducing educational inequalities between children from different social class backgrounds. Second, we investigated whether the institutional assimilation of the (former) GDR into the FRG with German unification led to a convergence of the level of IEO in East Germany towards that of West Germany.

Our first main finding is that IEO at the mid-secondary, upper-secondary and tertiary level was substantially lower in the GDR than in the FRG, even in the late phase of the GDR. This lower level of IEO in the GDR is likely to reflect the efforts of the GDR leadership to universalise mid-secondary education, as well as a range of 'counter-privileging' measures that sought to promote the educational attainment of children from working-class backgrounds at the upper-secondary and tertiary level. These measures included a quota-system that positively discriminated in favour of working-class children in the admission to upper-secondary schools (Erweiterte Oberschulen), as well as stipends and information campaigns targeted at increasing the participation of working-class children in tertiary education.

One further reason for the lower level of IEO between different social origin groups in the GDR as compared to the FRG may have been that - due to employment guarantees and the importance of political capital for individuals' labour market position in the GDR - individuals from advantaged backgrounds in the GDR were less dependent on and therefore less invested in maximising their educational attainment in order to maintain their parents' social status, relative to their counterparts in the FRG. Moreover, and given the goal of state socialism to equalise individuals' socio-economic position, it may be the case that the goal of status maintenance itself was less prominent in individuals' educational decision making in the GDR than was the case in the FRG.

Our second main finding is that IEO at the mid-secondary, upper-secondary and tertiary level in East Germany increased substantially after German unification and converged towards the level of IEO in West Germany. While the level of IEO at the 
mid-secondary level in East Germany remained somewhat below that of West Germany, the level of IEO at the upper-secondary and tertiary level all but resembled that of West Germany after unification. Children from working-class backgrounds in East Germany lost out most in relative terms after unification. They were overrepresented in the increased proportion of children leaving school before completing mid-secondary education and they hardly benefitted from the educational expansion that occurred at the upper-secondary and tertiary level in the wake of unification.

Our finding that the educational expansion at the upper secondary and tertiary level benefitted individuals from high social class backgrounds more than individuals from working-class backgrounds is in line with the Maximally Maintained Inequality (MMI) hypothesis. MMI predicts that an expansion in the overall share of education in a given society tends to primarily benefit individuals from more advantaged social backgrounds until the educational attainment of this group has reached the point of saturation, thus reinforcing educational inequalities between different social origin groups (Raftery and Hout, 1993). Interestingly, our findings on over-time change in the pattern of mid-secondary attainment in East Germany also suggest that the inverse of the MMI hypothesis appears to hold. Individuals from high social class backgrounds in East Germany were largely able to evade the declining trend in mid-secondary attainment after unification, whilst individuals from working-class backgrounds were most strongly affected.

Importantly, our multiple cohort design allowed us to examine whether the increase in IEO in East Germany after unification was merely a short-term phenomenon that may have been caused by the post-unification economic crisis, or whether the increase in IEO persisted in the long-run, reflecting the permanent changes in the institutional structure of the East German educational system and economy that occurred in the wake of unification. We find the latter to be the case, as the post-unification increase in IEO in East Germany was sustained across the three post-unification cohorts we examine.

In interpreting our results, it should be kept in mind that - for reasons of comparability of qualifications across East and West Germany - our analysis focuses on examining the main school-leaving qualifications and academic tertiary qualifications, rather than vocational qualifications. However, we do not expect the empirical patterns we observe to differ with respect to vocational qualifications. If anything, our estimates of the level of equality of educational opportunity in East Germany before unification are likely to be conservative estimates, given that the practice of awarding vocational qualifications on work-experience alone in the GDR is likely to have led to an even lower level of educational inequality between social origin groups with respect to vocational qualifications, as compared to general schoolleaving qualifications.

Our findings suggest that the results of the study by Kesler (2003) that showed little difference in IEO between East and West Germany before unification and no increase IEO in East Germany after unification are likely to be false negatives that are due to the very small sample size used in her study. By contrast, our findings are in line 
with studies from other post-socialist countries that have shown an increase in the intergenerational transmission of inequality after the post-socialist transition (Gerber and Hout, 2004, Lippényi and Gerber, 2016, and Bukodi and Goldthorpe, 2010; Jackson and Evans, 2017). This is likely to be a result of the fact that the main institutional changes in the educational system and economy that occurred under statesocialism in East Germany were common to most state-socialist countries at the time. For instance, most state-socialist states mandated compulsory schooling in comprehensive schools until the mid-secondary level and introduced measures that positively discriminated in favour of children from working-class backgrounds in the admission to upper-secondary and tertiary education (see Kogan et al., 2011; Diewald et al., 2006). These institutional changes were reversed during the post-socialist transition when early ability tracking was reintroduced, positive discrimination was abolished and parental choice for educational transitions was extended (see, e.g., Kogan et al., 2011, pp.16-26). Similarly, state-socialist countries adopted similar economic policies, characterised by strongly centralised economic planning and stateownership of enterprises. The economies of these countries were liberalised in the rapid process known as 'shock therapy' after the post-socialist transition (see, e.g., Kogan et al., 2011; Diewald et al., 2006; Jackson and Evans, 2011).

Last, our findings speak forcefully to the debate in social stratification research on the role of institutional change in the intergenerational transmission of inequality (Blossfeld and Shavit, 1993; Goldthorpe, 2016; Betthäuser, 2017; Esping-Andersen and Wagner, 2012). The tenor of much of the literature on this issue has been that educational inequality is highly persistent across generations and largely immune to efforts to decrease IEO by way of policy reforms. While our study does not allow us to identify the role of any specific institution in accounting for the east-west and overtime differences in IEO that we observe, it provides strong evidence that the combined institutional differences between the GDR and the FRG had a substantial effect on the relative level of IEO in the two countries and that the institutional restructuring of the East German educational system and economy after unification led to a marked increase in IEO. Clearly, the low level of IEO in the GDR came at a high cost to personal and political liberty. An important agenda for future research is to shed light on the role and relative importance of specific macro-level institutions in equalising educational opportunities across individuals from different social backgrounds, and to examine whether and how such reforms can be implemented without compromising personal and political liberties to the extent that it was the case in the GDR. 
${ }^{1}$ GDR statistics tend to be based on a very broad definition of 'the working class', which at times includes state bureaucrats. Furthermore, rather vague categories such as 'the intelligence' (die Intelligen 2 ) are used to describe privileged social groups (see, Below, 1997; Geißler, 1983).

2 See Erikson and Goldthorpe (1992) for a discussion of the importance of inequalities in parental economic resources for the intergenerational transmission of (dis-)advantage.

3 These Sperialschulen were designed to support exceptionally gifted children in achieving outstanding performances in the sciences, arts and sports. Only about 2-5 percent of pupils were enrolled in these Spezialschulen (Opitz, 1979; Meier and Reimann, 1977).

${ }^{4}$ The upper-secondary school track (Gymnasium) was reinstated as a school form in all East German states and even in states where the lower and mid-secondary tracks (Hauptschule and Realschule) were combined in one school - this was the case in Saxony and Thuringia - pupils were separated into distinct ability groups. The lower-secondary qualification (Hauptschulabschluss) after ninth grade was reestablished as a school leaving qualification.

${ }^{5}$ A similar research design has been used by Goldstein and Kreyenfeld (2011) to study the effects of German unification on fertility.

${ }^{6}$ Individuals were allocated to these cohorts based on their year of birth, and to East and West Germany based on whether they attended school in East or West Germany.

${ }^{7}$ For a detailed discussion of the advantages of multiple imputation using chained equations in research on social stratification see Kuha (2013).

${ }^{8}$ Where individuals where interviewed more than once, the information on educational attainment is taken from the last interview.

${ }^{9}$ We also ran all our models separately by gender, which led to the same conclusions for both women and men. Controlling for age is important particularly in the East German context, given the prominence of alternative avenues for obtaining secondary and tertiary qualifications (Geißler, 1983). ${ }_{10}$ We consider running binomial logit models on the entire sample to be preferable over restricting the sample to subsets of individuals as practiced in the Mare-Model approach to analysing educational inequalities. This allows us two avoid two considerable disadvantages associated with the latter approach. First, given that we are interested in over-time change in the level of IEO across birth cohorts, restricting the sample to those who qualify for a given educational transition is problematic, since the composition of this group is likely to vary considerably across cohorts, thus introducing severe selection biases into the analysis. Moreover, given the multiple routes to obtaining a given qualification, any attempt at identifying the group of individuals who qualify for a given educational transition is likely to be imprecise at best.

11 To confirm the statistical significance of the difference in IEO between East and West Germany before unification, we run a binary logit model for the combined pre-unification cohorts and compute the interaction between parental class and a dummy variable indicating whether individuals received their schooling in East or West Germany (See Table A2 in the Appendix). The statistically significant interaction confirms the difference in IEO at the mid-secondary level between East and West Germany that we observe in Figure 1.

12 Table A1 in the Appendix shows a substantial and statistically significant rise in the inequality between children from unskilled working-class backgrounds (the reference category) and children from intermediate class and salariat backgrounds for the last three cohorts. While the average marginal effects also suggest a rise in the educational inequality between children from unskilled and skilled working-class backgrounds, this is not statistically significant.

13 The statistical significance of this post-unification difference is indicated by the interaction in Table A2.

14 The statistical significance of this East-West difference is confirmed by the interaction shown in Table A4 in the Appendix.

15 The statistical significance of this increase in IEO after unification is confirmed by the interaction shown in Table A3 in the Appendix.

${ }^{16}$ The statistical significance of this East-West difference is confirmed by the interaction shown in Table A6 in the Appendix.

17 The statistical significance of this increase in IEO after unification is confirmed by the interaction shown in Table A5 in the Appendix. 
$\underline{\text { References }}$

Angrist, J. D., \& Pischke, J.-S. (2009). Mostly harmless econometrics. Princeton: Princeton University Press.

Below, S. von. (1997). Bildung und soziale Ungleichheit in Ostdeutschland. In R. Hauser \& T. Olk (Eds.), Soziale Sicherheit für alle? (pp. 135-171). Opladen: Leske and Budrich.

Betthäuser, B. (2017). Fostering Equality of Opportunity? Compulsory Schooling Reform and Social Mobility in Germany. European Sociological Review, 33(5), 633-644.

Blossfeld, H.-P. (1993). Changes in educational opportunities in the Federal Republic of Germany. In Y. Shavit \& H.-P. Blossfeld (Eds.), Persistent inequality. Boulder, Colorado: Westview Press.

Blossfeld, H.-P., \& Shavit, Y. (1993). Persisting Barriers: Changes in Educational Opportunities in Thirteen Countries. In Y. Shavit \& H.-P. Blossfeld (Eds.), Persistent inequality (pp. 1-23). Boulder, Colorado: Westview Press.

Breen, R., \& Goldthorpe, J. H. (1997). Explaining educational differentials: Towards a formal rational action theory. Rationality and society, 9(3), 275-305.

Bukodi, E., \& Goldthorpe, J. H. (2010). Market versus meritocracy: Hungary as a critical case. European Sociological Review, 26(6), 655-674.

Connelly, J. (2014). Captive University: The Sovietization of East German, Crech, and Polish Higher Education, 1945-1956. UNC Press Books.

Cortina, K. S., Baumert, J., Leschinsky, A., Mayer, K. U., \& Trommer. (2008). Das Bildungswesen in der Bundesrepublik Deutschland. Hamburg: Rowohlt.

Diewald et al. (2006): Diewald, M., Goedicke, A., \& Mayer, K. U. (2006). After the Fall of the Wall: Life Courses in the Transformation of East Germany. Stanford University Press.

Erikson, R. (1984). Social class of men, women and families. Sociology, 18(4), 500-514.

Erikson, R., \& Goldthorpe, J. (1992). The constant flux. Oxford: Clarendon Press.

Esping-Andersen, G., \& Wagner, S. (2012). Asymmetries in the opportunity structure: Intergenerational mobility trends in Europe. Research in Social Stratification and Mobility, 30(4), 473-487.

Fischer, A. (1992). Das Bildungssystem der DDR: Entwicklung, Umbruch und Nengestaltung seit 1989. Darmstadt: Wissenschaftliche Buchgesellschaft.

Gangl, M. (2010). Causal inference in sociological research. Annual Review of Sociology, $36,21-47$.

Gebel, M. (2011). Hard Times for the Less Educated. In I. Kogan, C. Noelke, \& M. Gebel (Eds.), Making the transition: Education and labor market entry in Central and Eastern Europe (pp. 58-85). Stanford University Press.

Geißler, R. (1983). Bildungschancen und Statusvererbung in der DDR. Kölner Zeitschrift Für Soziologie Und Sozialpsychologie, 35(4), 755-770.

Gerber, T. P., \& Hout, M. (1995). Educational Stratification in Russia During the Soviet Period. American Journal of Sociology, 101(3), 611-660.

Gerber, T. P., \& Hout, M. (2004). Tightening up: Declining class mobility during Russia's market transition. American Sociological Review, 69(5), 677-703. 
Goldstein, J. R., \& Kreyenfeld, M. (2011). Has East Germany overtaken West Germany? Recent trends in order-specific fertility. Population and Development Review, 37(3), 453-472.

Goldthorpe, J. H. (2016). Social class mobility in modern Britain: Changing structure, constant process. Journal of the British Academy, 4, 89-111.

Hauser, R., \& Becker, I. (2000). Der Einfluss des Steuer-und Transfersystems auf die Einkommensverteilung in den neuen und alten Bundesländern. In H.-H. Noll \& R. Habich (Eds.), Vom Zusammenwachsen einer Gesellschaft: Analysen zur Angleichung der Lebensverbültnisse in Deutschland. (pp. 63-82). Frankfurt: Campus Verlag.

Heyns, B., \& Bialecki, I. (1993). Educational Inequalities in Postwar Poland. In Y. Shavit \& H.-P. Blossfeld (Eds.), Persistent inequality: Changing educational attainment in thirteen countries. Boulder, Colorado: Westview Press.

Hunt, J. (2008). The economics of German reunification. In S. N. Durlauf \& L. Blume (Eds.), The New Palgrave Dictionary of Economics (Vol. 6). New York: Palgrave Macmillan.

Jackson, M. V., \& Evans, G. (2017). Rebuilding Walls: Market Transition and Social Mobility in the Post-Socialist Societies of Europe. Sociological Science, 4, 54-79.

Kehm, B. M. (2004). Hochschulen in Deutschland. Aus Politik. Und Zeitgeschichte: Beilage Zur Wochenzeitung Das Parlament, 109-119.

Kesler, C. (2003). Educational stratification and social change: Evidence from German unification. European Sociological Review, 19(5), 467-482.

Kogan et al. (2011): Kogan, I., Noelke, C., \& Gebel, M. (2011). Making the transition: Education and labour market entry in Central and Eastern Europe. Stanford University Press.

Kuha, J. (2013). Trends in intergenerational class mobility in Britain: New findings from the analysis of birth cohort data.

Lenski, G. (1994). New light on old issues: The relevance of "really existing socialist societies" for stratification theory. In D. B. Grusky (Ed.), Social stratification: Class, race, and gender in sociological perspective (pp. 55-61). Boulder, Colorado: Westview Press.

Lippényi, Z., \& Gerber, T. P. (2016). Inter-generational micro-class mobility during and after socialism: The power, education, autonomy, capital, and horizontal (PEACH) model in Hungary. Social Science Research, 58, 80-103.

Marggraf, H. J. (1993). Bildungswesen der ehemaligen DDR. In Statistisches Bundesamt (Ed.), Einführung in dei Bundesstatistik in den neuen Bundesländern (pp. 119-131). Stuttgart: Metzger-Pöschel.

Mateju, P. (1993). Who won and who lost in a socialist redistribution in Czechoslovakia. In Y. Shavit \& H.-P. Blossfeld (Eds.), Persistent inequality. Boulder, Colorado: Westview Press.

Mayer, K. U. (2006). After the fall of the wall: Living through the post-socialist transformation in East Germany. In M. Diewald, A. Goedicke, \& K. U. Mayer (Eds.), After the fall of the wall: Life courses in the transformation of East Germany (pp. 1-29). Stanford, California: Stanford University Press. 
Meier, A., \& Reimann, A. (1977). Überblick über Ergebnisse bildungssoziologischer Forschung in der DDR (Informationen zur soziologischen Forschung in der DDR No. 13) (pp. 1-37).

Mintrop, H., \& Weiler, H. (1994). The relationship between educational policy and practice: The reconstitution of the college-preparatory Gymnasium in East Germany. Harvard Educational Review Harvard Educational Review, 64(3), 247-278.

Opitz, G. (1979). Bildung für das ganze Volk. Berlin: Dietz.

Raftery, A. E., \& Hout, M. (1993). Maximally Maintained Inequality: Expansion, Reform, and Opportunity in Irish Education, 1921-75. Sociology of Education, 66(1), 41-62.

Rose, D., \& Harrison, E. (Eds.). (2010). Social class in Europe: An introduction to the European Socio-economic Classification. London: Routledge.

Schreier, G. (1996). Förderung und Auslese im Einheitsschulsystem Debatten und Weichenstellungen in der SBZ/DDR 1946 bis 1989. Böhlau, Köln; Weimar; Wien.

Solga, H. (1994). "Systemloyalität" als Bedingung sozialer Mobilität im

Staatssozialismus, am Beispiel der DDR. Berliner Journal Für Soziologie, 4(4), 523542.

Solga, H. (1997). Bildungschancen in der DDR. In S. Häder, H.-E. Tenorth, \& O. Anweiler (Eds.), Bildungsgeschichte einer Diktatur: Bildung und Erriebung in SBZ und DDR im historisch-gesellschaftlichen Kontext (pp. 275-294). Weinheim: Deutscher Studien Verlag.

Speder, Z., \& Habich, R. (1999). Income Dynamics in Three Societies: An Investigation of Social Dynamics Using "Old" and "New" Types of Indicators (No. FS III) (pp. 99403). Berlin: Wissenschaftszentrum für Sozialforschung.

Szelényi, S. (1998). Equality by design: The grand experiment in destratification in Socialist Hungary. Stanford, Calif.: Stanford University Press.

Szelényi, S., \& Aschaffenburg, K. (1993). Inequalities in educational opportunity in Hungary. In Y. Shavit \& H.-P. Blossfeld (Eds.), Persistent inequality. Boulder, Colorado: Westview Press.

Wagner, G., Frick, J., \& Schupp, J. (2007). The German Socio-Economic Panel Study (GSOEP): Scope, evolution and enhancements. Journal of Applied Social Science Studies, (127), 139-169.

Wasmer, M., Blohm, M., Walter, J., Scholz, E., \& Jutz, R. (2014). Konzeption und Durchführung der Allgemeinen Bevölkerungsumfrage der Sozialwissenschaften (ALLBUS) (GESIS Technical Report No. 22). Mannheim: GESIS.

White, I. R., Royston, P., \& Wood, A. M. (2010). Multiple imputation using chained equations: Issues and guidance for practice. Statistics in Medicine, 30(4), 377-399.

Windorf, P. (1996). Die Transformation der Ostdeutschen Betriebe. Berliner Journal Für Soziologie, 4, 467-488.

Wirth, H., Gresch, C., Müller, W., Pollak, R., \& Weiss, F. (2010). Measuring social class: The case of Germany. In D. Rose \& E. Harrison (Eds.), Social class in Europe: An introduction to the European Socio-economic Classification (pp. 114-137). London: Routledge. 